\title{
Partitioning of major and trace inorganic contaminants in fly ash acid mine drainage derived solid residues
}

\author{
${ }^{1 *}$ W. M. Gitari; ${ }^{2}$ L. F. Petrik; ${ }^{2}$ D. L. Key; ${ }^{3}$ C. Okujeni \\ ${ }^{1}$ Department of Ecology and Resource Management, School of Environmental Sciences, University of Venda, \\ South Africa \\ ${ }^{2}$ Chemistry Department, University of the Western Cape, South Africa \\ ${ }^{3}$ Department of Earth Sciences, University of the Western Cape, South Africa
}

Received 14 December 2009; ～revised 9 February 2010; accepted 19 May 2010; availaE@Honline 1 June 2010

\begin{abstract}
Acid mine drainage was reacted with coal fly ash over a $24 \mathrm{~h}$ reaction time and species removal trends evaluated. The evolving process water chemistry was modeled by the geochemical code PHREEQC using WATEQ4 database. Mineralogical analysis of the resulting solid residues was done by X-ray diffraction analysis. Selective sequential extraction was used to evaluate the transfer of species from both acid mine drainage and fly ash to less labile mineral phases that precipitated out. The quantity of fly ash, volume of acid mine drainage in the reaction mixture and reaction time dictated whether the final solution at a given contact time will have a dominant acidic or basic character. Inorganic species removal was dependent on the $\mathrm{pH}$ regime generated at a specific reaction time. Sulphate concentration was controlled by precipitation of gypsum, barite, celestite and adsorption on iron-oxy-hydroxides at $\mathrm{pH}>5.5$. Increase of $\mathrm{pH}$ in solution with contact time caused the removal of the metal ions mainly by precipitation, coprecipitation and adsorption. PHREEQC predicted precipitation of iron, aluminium, manganese-bearing phases at $\mathrm{pH}$ 5.53-9.12. An amorphous fraction was observed to be the most important in retention of the major and minor species at $\mathrm{pH}>6.32$. The carbonate fraction was observed to be an important retention pathway at $\mathrm{pH} 4-5$ mainly due to initial local pockets of high alkalinity on surfaces of fly ash particles. Boron was observed to have a strong retention in the carbonate fraction.
\end{abstract}

Keywords: Acid mine drainage; Fly ash; Neutralization; Residue; Sequential extraction

\section{INTRODUCTION}

Fly ash (FA) is a by-product obtained during the combustion of coal in coal burning power generation plants. South Africa coal burning power stations generate $26 \mathrm{Mt}$ of fly ash per year. This is set to increase until alternative sources of energy are fully developed and commercially exploited. Currently only $5 \%$ of the annual production is beneficially utilized as a cement extender (Krüger, 2003) as a soil ameliorant . The rest is stockpiled or slurried to ash dams (Mattigod et al., 1990; Abbott et al., 2001). Globally, about 88 million tons of fly ash, bottom ash, boiler slag and flue gas desulfurization (FGD) residues are generated in the United States annually and $22 \%$ of these solid wastes are used for beneficial purposes. In China, thermal power plants produce nearly 160 million tons and over

*Corresponding Author Email: mugera.gitari@univen.ac.za Tel.: 27159628572; Fax: +27219593878
$50 \%$ of the fly ash is used in different applications such as bricks manufacture, construction of dams and in the cement industry (Okafor and Opuene, 2007). FA tends to accumulate toxic elements such as heavy metals at the high temperatures involved during its generation (Eary et al., 1990; Spears and Lee, 2004) and is considered an environmental hazard in South Africa and other parts of the world. Anions $\left(\mathrm{Cl}^{-}, \mathrm{SO}_{4}^{2-}\right)$, oxy-anions of Se, As, Mo, B and $\mathrm{Cr}$ and cations (Al, $\mathrm{Fe}, \mathrm{Na}, \mathrm{K}, \mathrm{Ca}, \mathrm{Sr}, \mathrm{Ba}, \mathrm{Zn}, \mathrm{Cu}, \mathrm{Cd}$ and $\mathrm{Mg}$ ) are leached from the ash heaps by the wastewater derived from the ash slurry or by subsequent infiltration by rain upon disposal (Adriano et al., 1980; Eary et al., 1990; Mattigod et al., 1990; Reardon et al., 1995; Nameni et al., 2008). Of main environmental concern are the toxic trace elements, $\mathrm{Pb}, \mathrm{Cr}, \mathrm{B}, \mathrm{Mo}$, As and Se (Adriano et al., 1980; Carlson and Adriano, 1993; Abbott et al., 
2001; Spears and Lee, 2004) that are likely to leach upon disposal. The $\mathrm{pH}$ of a fly ash suspension for example in water can vary depending on the $\mathrm{S}$ content of the parent coal (Plank and Martens, 1974). Fly ash derived from anthracite coals are generally high in $\mathrm{S}$ and produce acidic fly ashes while fly ashes derived from lignite coals are low in $\mathrm{S}$ but high in $\mathrm{Ca}$ and produce alkaline ashes (Furr et al., 1977; Page et al., 1979). South African coal is sub-bituminous and generates fly ash that is characterized by low Fe content. The aqueous extracts of this fly ash are strongly alkaline $(\mathrm{pH} 12-$ 12.5) due to the free lime content (Foner et al., 1999; Gitari et al., 2006; Gitari et al., 2008).

Acid mine drainage (AMD) often contains high concentrations of heavy metals such as Fe, Mn, Al and anions like $\mathrm{SO}_{4}$ in addition to elements like $\mathrm{Zn}, \mathrm{Co}$, $\mathrm{Pb}, \mathrm{Cr}, \mathrm{Cu}$, in trace concentrations which necessitate these waters to be treated before release. Acid mine drainage (AMD) is produced when sulphide minerals, such as pyrite, found in association with the coal or overburden come into contact with oxygen and water during mining. Sulphide minerals undergo bacteriallycatalysed oxidation reactions which generate acidity and increases Fe, sulphate and other toxic elements concentrations in recipient water bodies (Eq. 1).

$\mathrm{FeS}_{2(\mathrm{~s})}+3.5 \mathrm{O}_{2}+\mathrm{H}_{2} \mathrm{O} \Rightarrow \mathrm{Fe}^{2+}+2 \mathrm{SO}_{4}^{2-}+2 \mathrm{H}^{+}$

Management of mine water pollution demands a range of active and passive remediation engineering technologies to minimize its impact on ground and surface waters which can incur significance expense (Younger et al., 2002).

The neutralization of AMD with various liming agents such as limestone (Cravotta and Mary, 1999; Maree et al., 1992) and lime (Jenke and Gordon, 1983) have been studied extensively. These are the main techniques applied in remediation of acidic mine waters. Some of the limitations of these treatment processes include armoring of limestone particles by the precipitating amorphous ferric hydroxides which reduce efficiency of neutralization and the maximum $\mathrm{pH}$ of 7 attained which leaves contaminants such as Mg largely in solution (Maree et al., 1996). A limitation of lime is the high cost involved (Maree et al., 1996). Fly ash has been evaluated by several researchers for its ability to control acid generation in sulphidic mine tailings and mine spoils (Abbott et al., 2001; Xenidis et al., 2002; Pérez-López et al., 2007a-c) and removal of contaminants from aqueous solution (Agyei et al., 2002;
Erol et al., 2005; Gitari et al., 2006; Abdel-Ghani et al., 2009). In all these applications the alkaline property of the fly ash was utilized to increase the $\mathrm{pH}$ of the solutions and consequently induce contaminants attenuation mechanisms such as precipitation, coprecipitation and adsorption. These authors also observed that the contaminant removal capacity of the fly ash depended strongly on their $\mathrm{CaO}$ content.

The highly soluble $\mathrm{CaO}$ occurring as sub-micron fragments on the fly ash particles makes it attractive as a liming agent for acidic mine water. In South Africa most power stations producing fly ash are located near the coal mining sites which adds on to the economic viability of the process in addition to being available in large quantities. This survey is a follow up of an article published earlier by the present article author and reported the application of fly ash to neutralize and remove major contaminants in AMD (Gitari et al., 2008). The temporal evolution of the leachate chemistry with time was evaluated. However this treatment option will lead to generation of solid residues that require disposal and one proposed disposal technique is backfill in mine voids. A limitation of the backfill application would be the possible leaching of trace elements with possible contamination of groundwater. In trying to address the suitability of the solid residues as possible backfill material, the present survey presents an assessment of the metal mobility in the solid residues from the AMD treatment. The survey traces the transformation of the contaminants both from AMD and fly ash as they interact and form secondary mineral phases and as the trace elements get adsorbed in the amorphous secondary phases formed. Understanding the physico-chemical phases that these elements partition on will greatly aid in predicting their possible leaching behaviour on disposal.

Phase-selective chemical extractions involving multiple extracting agents is one of the approachs utilized to understand the distribution of metals in a sediment (Tessier et al., 1979; Shuman, 1985; Ure et al., 1993). Metals in sediments or precipitates may be present in several different physicochemical phases that act as reservoirs or sinks of trace elements in the environments (Jenne, 1977; Beckett, 1988; Sposito, 1983; Mahvi, 2008). These phases include broad categories such as: water soluble, exchangeable; specifically adsorbed; carbonate; secondary Fe and Mn oxides; organic matter; sulphides and silicates. All of these may occur in a variety of structural forms. The 
sequential extraction schemes can be a very useful method, for characterizing solid phases associated trace elements in soils, sediments or particulates (Adamo et al., 1996; Ma and Rao, 1997; Mohsenzadeh et al., 2006; Karbassi et al., 2008; Feng et al., 2009). In this study, the sequential extraction procedure is intended to semiquantitatively evaluate the trends of mass transfer of major and selected trace elements from AMD and FA to the resulting precipitates admixed with residue matrix of the fly ash as the $\mathrm{pH}$ of the system evolves and also confirm to some extent the contaminants removal mechanisms observed in the treatment process.

\section{MATERIALS AND METHODS}

Sample description

The fly ash used was obtained directly from a coal combustion power generating station in South Africa and kept in tightly locked PVC buckets to prevent ingress of $\mathrm{CO}_{2}$ which leads to loss of alkalinity (Campbell, 1999). AMD samples were obtained from a coal washing plant in Mpumalanga, South Africa. The samples were scoped from a holding dam by use of $5 \mathrm{~L}$ high density polyethylene containers which were initially rinsed with $2 \%$ ultra-pure nitric acid solution. The containers were rinsed thoroughly with the AMD before sampling. Samples were preserved with ice in cool boxes until refrigeration in the laboratory. Total elemental analysis of FA and solid residues (SR) was done on powder briquettes by X-ray fluorescence (XRF) and reported in $\% \mathrm{w} / \mathrm{w}$ for major and $\mathrm{ppm}$ for trace elements. Samples of raw AMD and reaction mixture were filtered through a $0.45 \mu \mathrm{m}$ nucleopore membrane and the filtrate analysed for the major elements, trace elements and $\mathrm{SO}_{4}{ }^{2-}$. Cation analysis of the aqueous samples was done by inductively coupled plasma-mass spectrometer (ICP-MS: ELAN 6000). The accuracy of the analysis was monitored by use of NIST water reference material. $\mathrm{Fe}^{2+} / \mathrm{Fe}^{3+}$ analysis was done by the colorimetric method using 2,2-bipyridal as the complexing reagent. $\mathrm{SO}_{4}^{2-}$ analysis was done by Ion Chromatography (Dionex DX-120). The results of the chemical characterization of the samples used are presented in Tables 1 and 2.

\section{Neutralization reactions}

The fly ash/AMD neutralization experiments were conducted by stirring a mixture of fly ash and AMD in which the fly ash and AMD were weighed to give a specific FA: AMD ratio. Two FA: AMD ratios 1:3 and 1:1.5 were investigated. The AMD was stirred for $30 \mathrm{~min}$ for equilibration before the fly ash was added. An overhead stirrer was used for all the experiments. The progress of the reaction was monitored by measuring the $\mathrm{pH}$ and electrical conductivity (EC) with a Hanna HI 991301 portable $\mathrm{pH} / \mathrm{EC} / \mathrm{TDS} /$ temperature probe. The probe was calibrated for $\mathrm{pH}$ by use of buffer 4.01 and 7.01 and the accuracy ascertained with a buffer 10.01 solution. Conductivity calibration was ascertained by use of $12.88 \mathrm{mS} / \mathrm{cm}$ conductivity standard solution. The reactions were stopped at designated reaction times and $\mathrm{pH}$. The mixture was filtered through $0.45 \mu \mathrm{m}$ nucleopore membrane and the filtrate analyzed for the major elements, trace elements and $\mathrm{SO}_{4}{ }^{2-}$. Cation analysis of the water samples was done by ICP-MS (ELAN 6000). $\mathrm{SO}_{4}{ }^{2-}$ analysis was done by Ion Chromatography (Dionex DX-120).

\section{$X$-ray diffraction (XRD) analysis and calculation of saturation states}

XRD spectra of the powder mounts of the solid residues were obtained by step-scanning at intervals of $0.02^{\circ} 2 \theta$ from $5^{\circ}$ to $85^{\circ}$ and counted for $0.5 \mathrm{~s}$ per step. A Phillips PANalytical instrument was used with a pw3830 x-ray generator operated at $40 \mathrm{kV}$ and $25 \mathrm{~mA}$. The X'pert graphics and identify program was used to identify the mineral phases using the JCPDF database. Activities of aqueous species and mineral saturation indices of selected mineral phases were calculated using PHREEQC code (Parkhurst, 1995) and the WATEQ4F database (Ball and Nordstrom, 1991).

\section{Selective sequential extractions}

The extraction scheme adopted is a combination of the methods developed by Chao, (1972); Tessier et al. (1979) and Muller and Seiller (1999) with addition of the amorphous Fe, Mn and Al oxyhydroxide fraction. Six operational fractions were selected. One of the approachs to understand the distribution of metals in sediment is done by phase-selective chemical extractions involving multiple extracting agents (Tessier et al., 1979; Shuman 1985; Ure et al., 1993). The reagents utilized in sequential extraction are chosen such that they are selective and specific towards a particular physico-chemical form. The reagents destroy the binding agents between the metals and the sediments allowing them to be released into solution. Sequential extractions were performed on the equivalent masses 
ranging from 1-10 $\mathrm{g}$ dry matter for the solid residues recovered from the 1:3 FA: AMD reactions. The $\%$ moisture content of the solid residues were determined on separate portion of the wet solid residues by drying at $105^{\circ} \mathrm{C}$ for $12 \mathrm{~h}$ for each extraction and this value was used to calculate the mass of dry solid residues used in each experiment. The extraction was carried out by agitating the samples in a table shaker.

After each extraction, samples were centrifuged at $1000 \mathrm{rpm}$ for $10 \mathrm{~min}$ and the supernatant filtered through a $0.45 \mu \mathrm{m}$ nucleopore membrane. The extracted solid residue sample was then washed with milliQ water, centrifuged, the supernatant decanted and discarded. The extraction was done in triplicate. For each extraction a blank sample was prepared using the extraction reagents and analyzed to account for any background contribution. In addition NIST-1640 water standard reference material was analyzed for every batch of 20 samples for quality control. The extraction was done for both the fresh FA and solid residues (SR) recovered at $\mathrm{pH} 4,4.92,6.32$ and 9.12 for FA: AMD ratio of 1:3.The extraction sequence consisted of six stages.

The procedure for extraction was as follows:

- Water soluble fraction- $10 \mathrm{~g}$ of the wet solid residues in $100 \mathrm{~mL}$ MilliQ water were agitated for $1 \mathrm{~h}$. This sample was initially washed by shaking with $10 \mathrm{~mL}$ MilliQ water for $5 \mathrm{~min}$ and the liquid extract discarded. This was done to remove the dissolved components from the batch experiments.

- Exchangeable fraction-7 g of wet solid residues recovered from the water soluble fraction was extracted with $70 \mathrm{~mL}$ of $\mathrm{MgCl}_{2}$ solution $\left(1 \mathrm{M} \mathrm{MgCl}_{2}\right.$ solution) at $\mathrm{pH} 7$, by continuous agitation for $1 \mathrm{~h}$ at room temperature (Tessier et al., 1979).

- Carbonate fraction-6 g of the wet solid residues recovered from the exchangeable fraction were extracted with $60 \mathrm{~mL}$ of $1 \mathrm{M}$ sodium acetate/acetic acid buffer solution at $\mathrm{pH} 5$ by agitating continuously for $5 \mathrm{~h}$ (Tessier et al., 1979).

- Crystalline Mn-oxides -5 g of the wet solid residues recovered from the carbonate fraction were extracted with $125 \mathrm{~mL}$ of $0.1 \mathrm{M}$ hydroxylamine hydrochloride prepared in $0.01 \mathrm{M} \mathrm{HNO}_{3}$ at $\mathrm{pH} 2$ for $30 \mathrm{~min}$ by continuous agitation (Chao, 1972; Shuman, 1985).

- Amorphous Fe, Mn, Al- oxides, (oxy) hydroxides-4 g of the wet solid residues recovered from the crystalline Mn-oxide fraction was extracted with 800
$\mathrm{mL}$ of the $0.2 \mathrm{M}$ ammonium oxalate/oxalic acid buffer at $\mathrm{pH} 3$ for $4 \mathrm{~h}$ in the dark (Cornell and Schwertmann, 1996).

- Crystalline Fe oxides-2- $2.5 \mathrm{~g}$ of the wet solid residues recovered from the amorphous Fe, Mn, Al- oxides, (oxy) hydroxides fraction were extracted with 60-75 $\mathrm{mL}$ of ammonium oxalate monohydrate $0.2 \mathrm{M}+$ oxalic acid $0.2 \mathrm{M}+0.1 \mathrm{M}$ ascorbic acid mixture at $\mathrm{pH} 3.25$ by agitating for $30 \mathrm{~min}$ in a water bath maintained at $95 \pm 5^{\circ} \mathrm{C}$ (Muller and Seiller, 1999).

Between each extraction step a sub-sample was kept aside for moisture content determination.

\section{RESULTS AND DISCUSSION}

Chemical characterization of fly ash and acid mine water

The XRF results (Table 1) show that the fly ash consists of three main components: $\mathrm{Al}_{2} \mathrm{O}_{3}, \mathrm{Fe}_{2} \mathrm{O}_{3}$ and $\mathrm{SiO}_{2}$ confirming that it's an alumino-silicate material. Major phases detected by XRD were mullite and quartz (data not shown). Among the minor elements, $\mathrm{Sr}, \mathrm{Ba}$, $\mathrm{Cr}, \mathrm{Zr}$ and Ni occur in high concentration. Traces of Mo are also present. These concentrations are within the ranges reported by Eary et al. (1990). The AMD is strongly acidic ( $\mathrm{pH}$ 2.19). Major elements include $\mathrm{Al}$, $\mathrm{Mn}, \mathrm{Fe}^{3+}, \mathrm{Fe}^{2+}$ and $\mathrm{SO}_{4}^{2-}$. The AMD has high $\mathrm{SO}_{4}^{2-}$ content (Table 2) typical of leachate from sulphide rich coal mine tailings and underground mine water (Uhlmann et al., 2004).

\section{Composition of solid residues}

The results of XRF analysis of the SR samples collected at $\mathrm{pH} 9.0$ for 1:3, FA: AMD ratio are shown in Table 1. A comparison of the composition of FA and the SR indicates a decrease in $\mathrm{SiO}_{2}, \mathrm{CaO}$ and $\mathrm{MgO}$. The decrease in $\mathrm{SiO}_{2}$ reflects the dissolution of amorphous $\mathrm{SiO}_{2}$ at low $\mathrm{pH}$ while the decrease in $\mathrm{CaO}$ and $\mathrm{MgO}$ content in the solid residues reflects the dissolution of free lime and $\mathrm{MgO}$ which is responsible for the neutralizing capacity of the fly ash. An increase in $\mathrm{Fe}_{2} \mathrm{O}_{3}, \mathrm{Al}_{2} \mathrm{O}_{3}$ and $\mathrm{MnO}$ in the solid residues indicates the removal of these elements from AMD as insoluble precipitates.

Reaction of acid mine drainage with fly ash: $p H$ profiles.

The evolution of $\mathrm{pH}$ values with time for the $1: 3$ and 1:1.5 FA: AMD ratios are presented in Fig. 1a. The $\mathrm{pH}$ values for the 1:3 ratio are characterized by 
Int. J. Environ. Sci. Tech., 7 (3), 519-534, Summer 2010

Table 1: Composition of fly ash and solid residues collected at $\mathrm{pH} 9.2$ for 1:3: fly ash: acid mine drainage ratio

\begin{tabular}{|c|c|c|c|c|c|}
\hline \multicolumn{4}{|c|}{ Fly ash } & \multicolumn{2}{|c|}{ Solid residues (SR) } \\
\hline Elements & Concentration (\% w/w) & Elements & Concentration (mg/kg) & Elements & Concentration (\% w/w) \\
\hline $\mathrm{SiO}_{2}$ & $52.4 \pm 2.360$ & $\mathrm{Cu}$ & $45.3 \pm 6.600$ & $\mathrm{SiO}_{2}$ & $45.81 \pm 3.600$ \\
\hline $\mathrm{TiO}_{2}$ & $1.34 \pm 0.050$ & Mo & $5.5 \pm 1.230$ & $\mathrm{TiO}_{2}$ & $1.29 \pm 0.060$ \\
\hline $\mathrm{Al}_{2} \mathrm{O}_{3}$ & $23.4 \pm 1.080$ & $\mathrm{Ni}$ & $92.4 \pm 6.500$ & $\mathrm{Al}_{2} \mathrm{O}_{3}$ & $22.57 \pm 2.100$ \\
\hline $\mathrm{Fe}_{2} \mathrm{O}_{3}$ & $4.72 \pm 0.960$ & $\mathrm{~Pb}$ & $57.4 \pm 13.60$ & $\mathrm{Fe}_{2} \mathrm{O}_{3}$ & $6.31 \pm 1.290$ \\
\hline $\mathrm{MnO}$ & $0.06 \pm 0.001$ & $\mathrm{Sr}$ & $1465.9 \pm 113.8$ & $\mathrm{MnO}$ & $0.1 \pm 0.010$ \\
\hline $\mathrm{MgO}$ & $2.67 \pm 0.035$ & $\mathrm{Zn}$ & $54.3 \pm 4.710$ & $\mathrm{MgO}$ & $2.33 \pm 0.650$ \\
\hline $\mathrm{CaO}$ & $8.41 \pm 0.574$ & $\mathrm{Zr}$ & $478.1 \pm 125.7$ & $\mathrm{CaO}$ & $7.18 \pm 2.620$ \\
\hline $\mathrm{Na}_{2} \mathrm{O}$ & $0.35 \pm 0.253$ & Co & $16.2 \pm 13.08$ & $\mathrm{Na}_{2} \mathrm{O}$ & $0.4 \pm 0.014$ \\
\hline $\mathrm{K}_{2} \mathrm{O}$ & $0.48 \pm 0.032$ & $\mathrm{Cr}$ & $181.2 \pm 1.140$ & $\mathrm{~K}_{2} \mathrm{O}$ & $0.53 \pm 0.130$ \\
\hline $\mathrm{P}_{2} \mathrm{O}_{5}$ & $0.34 \pm 0.212$ & $\mathrm{~V}$ & $147.4 \pm 39.00$ & $\mathrm{P}_{2} \mathrm{O}_{5}$ & $0.63 \pm 0.040$ \\
\hline $\mathrm{Cr}_{2} \mathrm{O}_{3}$ & $0.03 \pm 0.009$ & $\mathrm{Ba}$ & $931 \pm 95.20$ & $\mathrm{Cr}_{2} \mathrm{O}_{3}$ & NA \\
\hline $\mathrm{SO}_{3}$ & NA & & & $\mathrm{SO}_{3}$ & $3.52 \pm 0.210$ \\
\hline
\end{tabular}

Results presented as mean \pm SD for $\mathrm{N}=3$

Table 2: Chemical and physical characteristics of acid mine drainage (concentration in mg/L except for $\mathrm{pH}$, EC and acidity)

\begin{tabular}{lrrr}
\hline Parameter & Concentration & Parameter & Concentration \\
\hline $\mathrm{pH}$ & $2.19 \pm 0.02$ & $\mathrm{Ni}$ & $6.16 \pm 1.230$ \\
$\mathrm{EC}(\mathrm{mS} / \mathrm{cm})$ & $15.77 \pm 0.01$ & $\mathrm{Cu}$ & $7.10 \pm 2.140$ \\
Acidity $(\mathrm{mmol} \mathrm{H} / \mathrm{L})$ & $289 \pm 1.01$ & $\mathrm{Zn}$ & $15.71 \pm 3.460$ \\
$\mathrm{~B}$ & $10.3 \pm 1.26$ & $\mathrm{Se}$ & $10.39 \pm 0.023$ \\
$\mathrm{Na}$ & $102.9 \pm 10.6$ & $\mathrm{Sr}$ & $\mathrm{Mo}$ \\
$\mathrm{Mg}$ & $399.4 \pm 30.7$ & $\mathrm{Ba}$ & $0.014 \pm 0.002$ \\
$\mathrm{Al}$ & $453.4 \pm 17.9$ & $\mathrm{~Pb}-$ & $0.108 \pm 0.003$ \\
$\mathrm{Si}$ & $99.2 \pm 9.43$ & $\mathrm{SO}_{4}{ }^{2-}$ & $0.455 \pm 0.022$ \\
$\mathrm{Ca}$ & $146.9 \pm 12.5$ & $\mathrm{Cl}^{-}$ & $24880 \pm 96.70$ \\
$\mathrm{Mn}$ & $95.8 \pm 7.89$ & $\mathrm{NO}^{3-}$ & $370 \pm 55.60$ \\
$\mathrm{Fe}^{2+}$ & $4444.9 \pm 59.8$ & & $90 \pm 20.30$ \\
$\mathrm{Fe}^{3+}$ & $2065.6 \pm 10.3$ & & \\
\hline
\end{tabular}

Results presented as mean \pm SD for $\mathrm{N}=3$

two buffer regions, at $\mathrm{pH} 4-4.5$ and $\mathrm{pH}$ 6.0. The 1:1.5 ratio shows two buffer regions, at $\mathrm{pH} 4.5-5.0$ and at pH 9.0. However, the buffering exhibited by the AMD at the $1: 1.5$ ratio is stronger. This is evident from the lower gradient of the curves at this buffer region for this ratio. The dissolution of oxide components such as $\mathrm{CaO}$ and $\mathrm{MgO}$ (Table 1) from fly ash contributes to an increase in solution $\mathrm{pH}$.

Offsetting the $\mathrm{pH}$ increase is the hydrolysis of AMD constituents such as $\mathrm{Fe}^{3+}, \mathrm{Al}^{3+}$, oxidation of $\mathrm{Fe}^{2+}$ to $\mathrm{Fe}^{3+}$ and subsequent hydrolysis to ferric hydroxides, this would explain the strong buffering plateaus observed at $\mathrm{pH}$ 4-6.5.

Profiles of the major and minor inorganic contaminants with reaction time

The trends of the major inorganic species are shown in Figs. 1 b- $j$ while the minor and trace inorganic species in the process waters with reaction time and $\mathrm{pH}$ for both ratios are shown in Table 3 .

\section{Sulphate}

The AMD samples were characterized by high $\mathrm{SO}_{4}^{2-}$ levels (24880 mg/L) (Fig. 1 b). A decreasing $\mathrm{SO}_{4}^{2-}$ concentration to a minimum was observed with time for both FA: AMD ratios. The 1:1.5 ratio registered a large decrease at $\mathrm{pH}>7$ than the $1: 3$ ratio. The fact that $\mathrm{SO}_{4}{ }^{2-}$ concentration did not double on increasing the amount of fly ash in the mixture (i.e, 1:1.5 FA: AMD ratio) means that a solubility control for $\mathrm{SO}_{4}^{2}$ exists. The increase in $\mathrm{pH}$ of the reaction mixture is attributed to the dissolution of $\mathrm{CaO}$ in the fly ash releasing $\mathrm{Ca}^{2+}$ ions which interacts with $\mathrm{SO}_{4}{ }^{2-}$ to form gypsum. Geochemical calculations with PHREEQC predicted saturation of the solution with gypsum for the entire reaction time for both ratios (Figs. $2 \mathrm{a}$ and $\mathrm{b})$. In addition

Al-(oxy)hydroxysulphates such as alunite, basaluminite and jurbanite could also have contributed to low $\mathrm{SO}_{4}^{2-}$ levels at $\mathrm{pH}<7$. PHREEQC predicted saturation of the process waters with these oxy hydroxysulphates at $\mathrm{pH}<7$ (Fig. $2 \mathrm{c}$ and d). Fe-(oxy) hydroxides precipitating at $\mathrm{pH}>7$ are also known to 
W. M. Gitari et al.
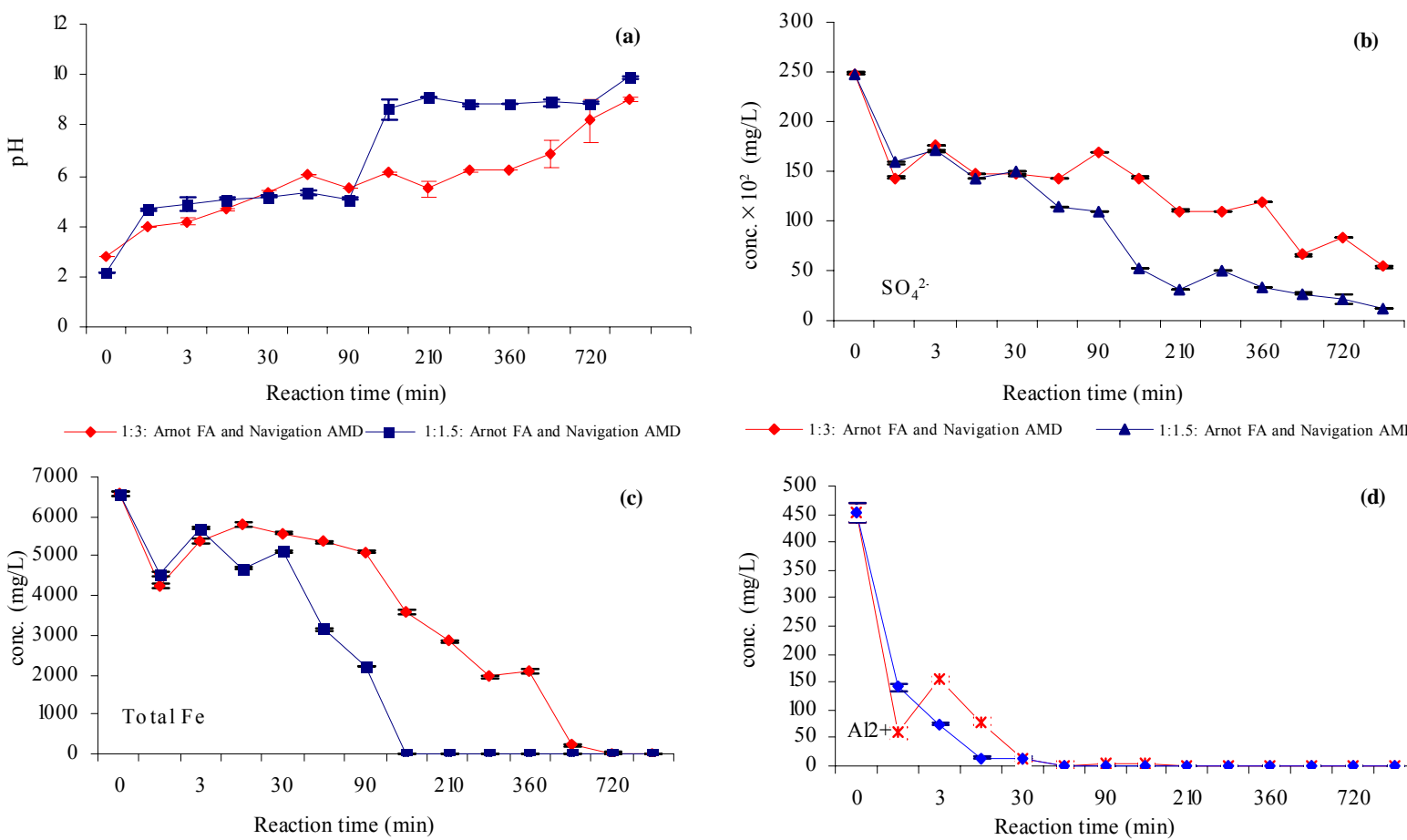

$\longrightarrow$ 1:3: Arnot FA and Navigation AMD $\_$1:1.5: Arnot FA and Navigation AMD

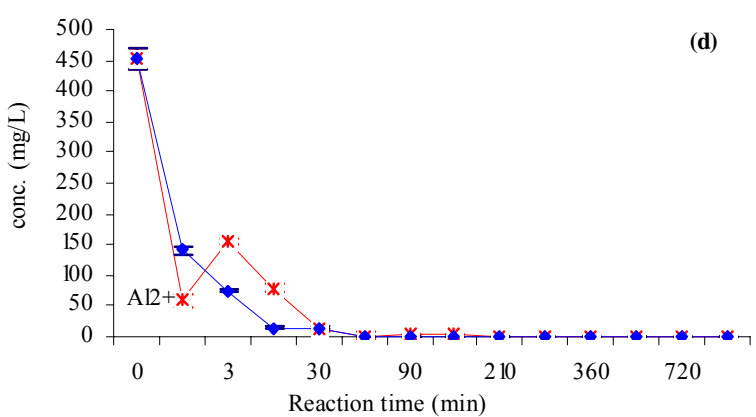

$\longrightarrow$ 1:3: Arnot FA and Navigation AMD $\longrightarrow$ 1:1.5: Arnot FA and Navigation AMD

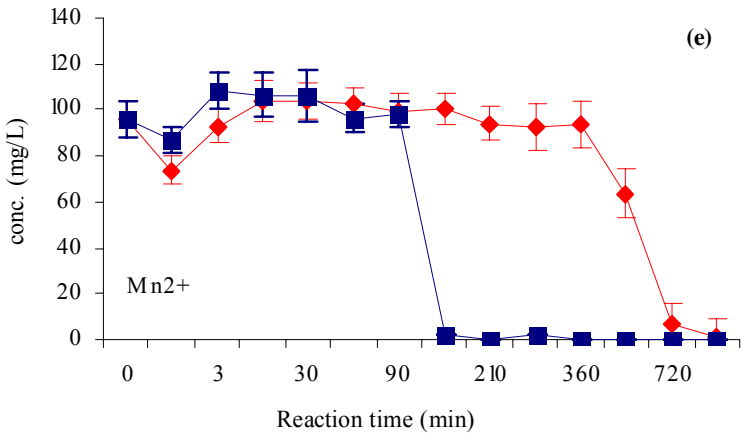

$-\mathbb{*}-1: 3$ : Arnot FA and Navigation AMD $\longrightarrow$ 1:1.5: Arnot FA and Navigation AMD

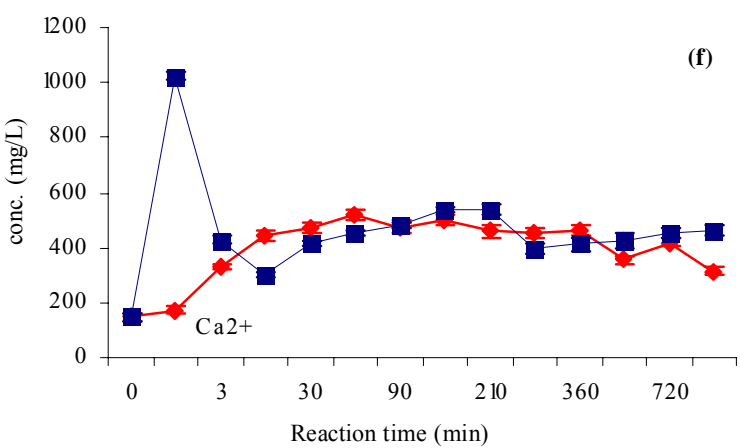

$\longrightarrow$ 1:3: Arnot FA and Navigation AMD 1:1.5: Arnot FA and Navigation AMD

1:3: Arnot FA and Navigation AMD $\multimap$ 1:1.5: Arnot FA and Navigation AMD
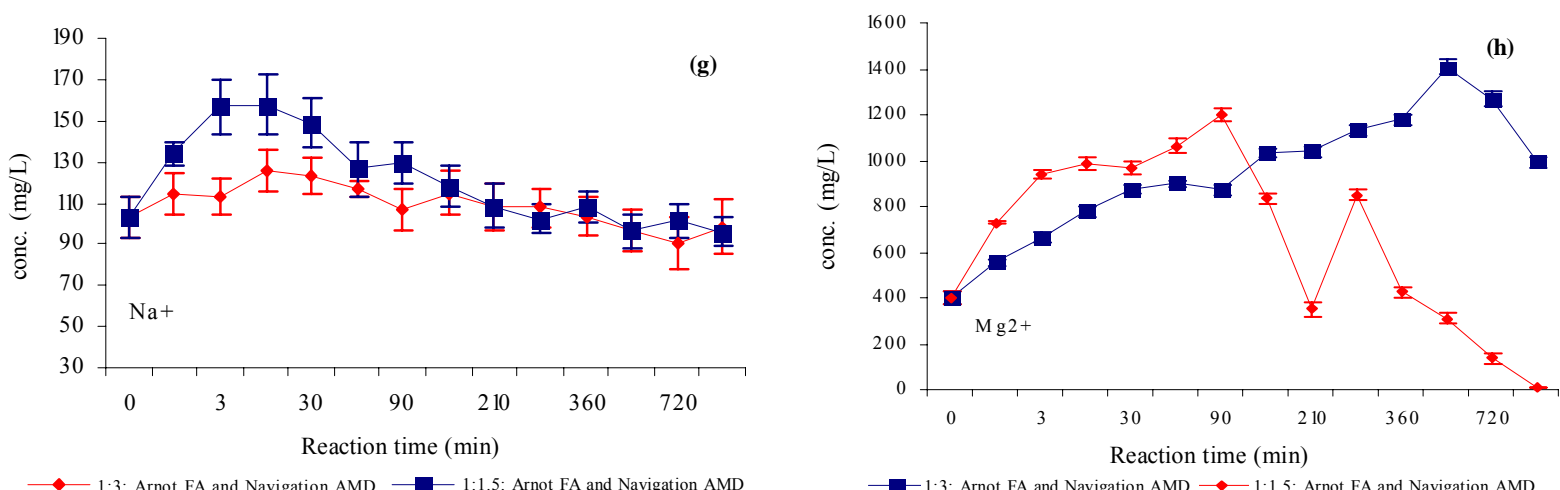

Fig. 1: Variation of $\mathrm{pH}, \mathrm{SO}^{2-}, \mathrm{Al}^{3+}$, Total $\mathrm{Fe}, \mathrm{Ca}^{2+}, \mathrm{B}, \mathrm{Mn}^{2+}, \mathrm{Mg}^{2+}, \mathrm{Sr}$ and $\mathrm{Na}^{+}$with reaction time (min) in process waters for $1: 3$ and 1:1.5 FA: AMD ratio. Error bar represents 1 SD above and below the mean $(\mathrm{N}=3)$ (Gitari et al., 2008). Reproduced with permission from Elsevier publishers. 

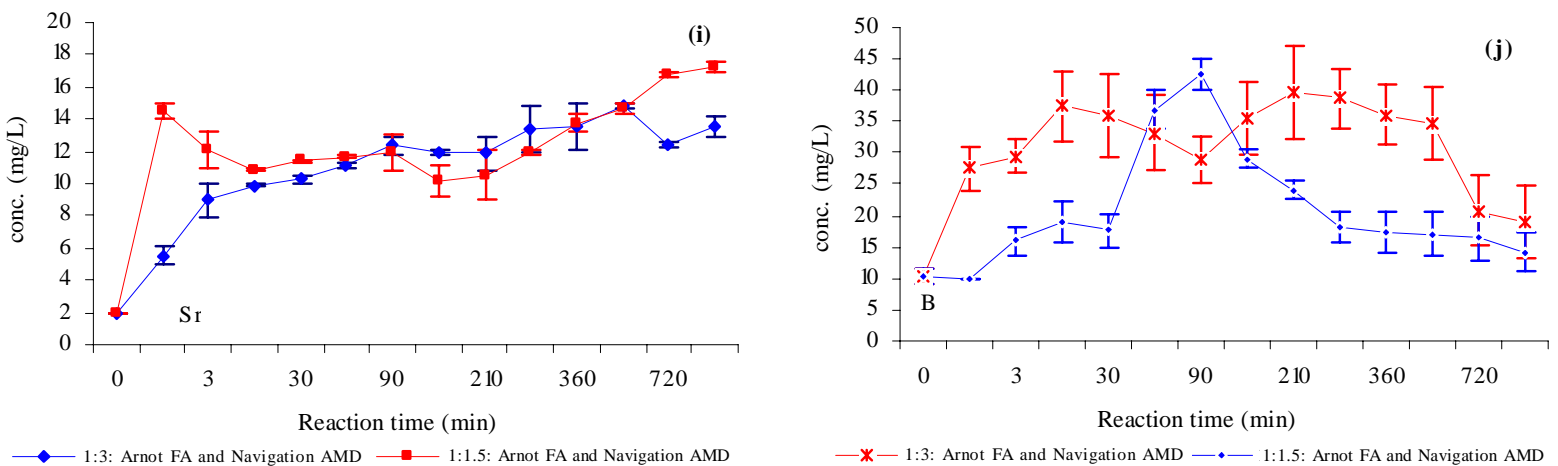

Fig. 1 (Continued): Variation of $\mathrm{pH}, \mathrm{SO}^{2-}, \mathrm{Al}^{3+}$, Total $\mathrm{Fe}, \mathrm{Ca}^{2+}, \mathrm{B}, \mathrm{Mn}^{2+}, \mathrm{Mg}^{2+}, \mathrm{Sr}$ and $\mathrm{Na}^{+}$with reaction time (min) in process waters for 1:3 and 1:1.5 FA: AMD ratio. Error bar represents $1 \mathrm{SD}$ above and below the mean $(\mathrm{N}=3)$ (Gitari et al., 2008) Reproduced with permission from Elsevier publishers.

Table 3: Minor and trace contaminants removal as a function of $\mathrm{pH}$ and reaction time (min) for FA: AMD ratios of 1: 3 and 1:1.5

\begin{tabular}{|c|c|c|c|c|c|}
\hline \multicolumn{6}{|c|}{ 1:3 FA: AMD ratio } \\
\hline Reaction time (min) & AMD & 3 & 15 & 270 & 1440 \\
\hline Elements & \multicolumn{5}{|c|}{ Concentration in mg/L except $\mathrm{pH}$} \\
\hline $\mathrm{Si}$ & $99.16 \pm 9.430$ & $74.64 \pm 6.400$ & $65.26 \pm 4.580$ & $6.71 \pm 0.980$ & $0.853 \pm 0.003$ \\
\hline $\mathrm{Zn}$ & $15.71 \pm 3.460$ & $14.18 \pm 2.350$ & $13.37 \pm 1.070$ & $0.783 \pm 0.023$ & $0.192 \pm 0.001$ \\
\hline Se & $0.390 \pm 0.023$ & $0.119 \pm 0.004$ & $0.027 \pm 0.002$ & $0.032 \pm 0.002$ & $0.146 \pm 0.003$ \\
\hline Mo & $0.014 \pm 0.002$ & $0.027 \pm 0.030$ & $0.057 \pm 0.003$ & $0.163 \pm 0.001$ & $0.834 \pm 0.003$ \\
\hline $\mathrm{pH}$ & $2.78 \pm 0.010$ & $4.17 \pm 0.010$ & $4.92 \pm 0.100$ & $6.32 \pm 0.030$ & $9.12 \pm 0.005$ \\
\hline \multicolumn{6}{|c|}{ 1:1.5 FA: AMD ratio } \\
\hline Reaction time (min) & AMD & 3 & 30 & 90 & 480 \\
\hline Elements & \multicolumn{5}{|c|}{ Concentration in mg/L except $\mathrm{pH}$} \\
\hline $\mathrm{Si}$ & $99.16 \pm 9.430$ & $95.6 \pm 6.54$ & $77.64 \pm 3.980$ & $14.5 \pm 3.410$ & $1.19 \pm 0.011$ \\
\hline $\mathrm{Cu}$ & $7.1 \pm 2.140$ & $7.79 \pm 1.302$ & $7.55 \pm 0.431$ & $0.782 \pm 0.017$ & $0.009 \pm 0.003$ \\
\hline
\end{tabular}

adsorb large quantities of $\mathrm{SO}_{4}^{2}$ and could also have contributed to the low levels observed (Seth and Elliot, 2000).

\section{Total Iron}

Both ratios registered greater than $90 \%$ removal on the reaction mixture attaining $\mathrm{pH}$ greater than 7 (Fig. 1c). The initial decrease in concentration for both ratios at $\mathrm{pH}$ 4-4.5 indicates removal of $\mathrm{Fe}^{3+}$ inform of hydroxides or oxyhydroxysulphates. The significant drop observed at $\mathrm{pH}$ greater than 7 is attributed to the rapid oxidation of $\mathrm{Fe}^{2+}$ and subsequent hydrolysis of $\mathrm{Fe}^{3+}$ to form insoluble hydroxides. Optimum oxidation of $\mathrm{Fe}^{2+}$ occurs at $\mathrm{pH} \approx 7$ (Stumm and Lee, 1961). The AMD samples were characterized by high concentrations of $\mathrm{Fe}^{2+}$ as compared to $\mathrm{Fe}^{3+}$ (Table 2). Geochemical calculations indicated that the solution was over-saturated with $\mathrm{Fe}(\mathrm{OH})_{3(a)}$, goethite, ferrihydrite and hematite for both ratios (Figs. 2 e and f). In our previous reported findings (Gitari et al., 2008) although schwertmannite was predicted to be precipitating, activity plots revealed that the ferric hydroxides were controlling the $\mathrm{Fe}^{3+}$ activity in the process waters. Substitution or adsorption of $\mathrm{SO}_{4}^{2-}$ for hydroxide ions on ferrihydrite and formation of schwertmannite-like phase has been proposed and could also have contributed to low levels of $\mathrm{SO}_{4}^{2-}$ (Nordstrom and Alpers, 1999). XRD analysis however did not reveal any Fe-bearing mineral phases probably due to their amorphous nature.

\section{Aluminium}

For both ratios $\mathrm{Al}$ concentration was observed to 
Utilization of fly ash for treatment of coal mines wastewater
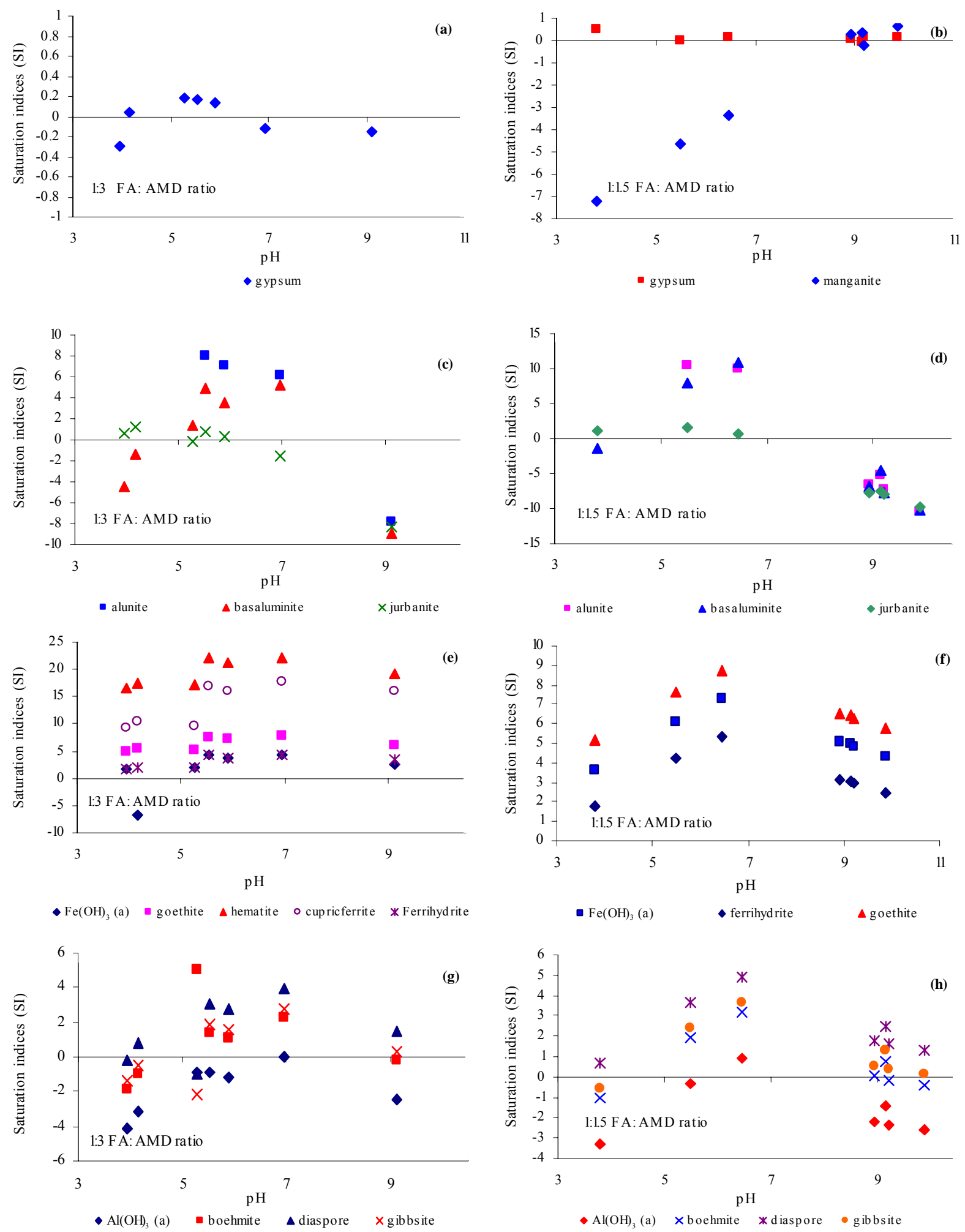

Fig. 2: Saturation indices of selected mineral phases for 1:3 and 1:1.5 FA: AMD ratios as a function of $\mathrm{pH}$ 
decrease steadily with increasing $\mathrm{pH}$ (Fig. 1d). At pH greater than $5,95 \%$ of the $\mathrm{Al}$ was removed from solution. Geochemical calculations with PHREEQC indicated that the solutions were over-saturated with jurbanite at $\mathrm{pH}$ 3.96-5.9, basaluminite, boehmite and alunite at $\mathrm{pH} 5.28-6.95$, gibbsite and diaspore at $\mathrm{pH}$ 5.53-9.12 (Figs. $2 \mathrm{~g}$ and $\mathrm{h}$ ).

\section{Silicon}

A steady decline in Si concentration was observed for both ratios as the $\mathrm{pH}$ increased (Table 3 ). The decrease in $\mathrm{Si}$ was attributed to formation of $\mathrm{Ca}-\mathrm{Si}-\mathrm{O}$, $\mathrm{Ca}-\mathrm{Mg}-\mathrm{Si}-\mathrm{O}$ rich gels as the $\mathrm{pH}$ increased. Previous SEM-EDX analysis of the solid residues from neutralization of AMD by fly ash indicated presence of Ca-Mg-Si rich gels (Gitari et al., 2008).

\section{Manganese}

Both ratios exhibited a similar trend in the removal of $\mathrm{Mn}^{2+}$. Concentrations were observed to increase to a maxima at $\mathrm{pH}$ 4.5-4.9 for both ratios. Near complete removal of $\mathrm{Mn}^{2+}$ was observed as the reaction mixture attained pH 7-9 (Fig. 1e). PHREEQC geochemical calculations indicated the solution to be at saturation or over-saturation with manganite at $\mathrm{pH}$ greater than 8.5 for ratio $1: 1.5$ (Fig. $2 b$ ).

\section{Zinc, Copper and Lead}

$\mathrm{Cu}$ exhibited different removal trends for the two FA: AMD ratios. For 1:3 FA: AMD ratio a significant drop was observed at $\mathrm{pH}$ e" 4 while for 1:1.5 FA: AMD ratio a significant drop was observed at $\mathrm{pH}>5.7$ (Table $3)$. In the 1:3 FA: AMD ratio removal of $\mathrm{Cu}$ could be mainly through adsorption on the iron (oxy) hydroxides that formed during the neutralization process while in $1: 1.5$ ratio it could be attributed to precipitation reactions. According to Brittons (1956) Cu hydroxide precipitates at $\mathrm{pH} \approx 5.3$ while $\mathrm{Zn}$ hydroxide precipitates at $\mathrm{pH}$ 7. Zn removal followed a similar pattern for both ratios with concentration significantly reducing at $\mathrm{pH}$ e" 6 suggesting precipitation as the main mechanism. PHREEQC simulation predicted the solution to be super-saturated with CupricFerrite $\left(\mathrm{CuFe}_{2} \mathrm{O}_{4}\right)$ suggesting co-precipitation as the main mechanism responsible for $\mathrm{Cu}$ removal (Fig. $2 \mathrm{e}$ ). Pb removal in the process water followed the same trend in both ratios (Table 3). Concentration decreased steadily with increasing $\mathrm{pH}$ to near detection limits at $\mathrm{pH} \approx 9$. The removal trends suggest precipitation as the main mechanism responsible for $\mathrm{Pb}$ removal.

\section{Sodium, magnessium, calcium and strontium}

These species in addition to their presence in AMD are also released in significant quantities in the reaction mixture. Their release results from dissolution of their soluble salts on the surface of the fly ash particles. The concentration profile reveals a peak at between 15-270 min of reaction time for 1:3 ratio and between $30-90 \mathrm{~min}$ of reaction time for 1:1.5 ratio, the concentration was observed to decrease as the $\mathrm{pH}$ increased. A substantial concentration of these species remains largely in solution compared to the initial concentration in the AMD (Figs. $1 \mathrm{f}-\mathrm{i}$ ). PHREEQC modeling predicted formation of Na-jarosite at $\mathrm{pH}$ (3.8-6.95) and celestite at $\mathrm{pH}$ (3.8-9.88) for both ratios. $\mathrm{Ca}$ plays a significant role in the removal of $\mathrm{SO}_{4}^{2-}$ as gypsum (Figs. $2 \mathrm{a}$ and $\mathrm{b}$ ).

\section{Boron, molybdenum and selenium}

Boron is one of the highly mobile elements associated with fly ash. A steady increase in concentration to a maxima for $\mathrm{B}$ was observed for both ratios with a significant decrease at $\mathrm{pH} \geq 9$ (Fig. $1 \mathrm{j}$ ). The decrease in $\mathrm{B}$ at alkaline $\mathrm{pH}$ has been attributed to its interaction with $\mathrm{Ca}$-bearing mineral phases such as calcite and ettringite (Kitano et al., 1978; Akira et al., 2005). SEM analysis revealed presence of ettringite for solid residues collected at $\mathrm{pH}$ e" 9 in previous AMD neutralization experiments with fly ash (Gitari et al., 2008). Mo remained below $0.3 \mathrm{mg} / \mathrm{l}$ at $\mathrm{pH}<6.32$ for both ratios (Table 3 ). The concentration significantly increased for both ratios at $\mathrm{pH}$ e" 9. Mo exists as the $\mathrm{MoO}_{4}{ }^{2-}$ ion at $\mathrm{pH}>3$ (Eary et al., 1990) and it is likely that it was removed as metal molybdates at $\mathrm{pH}<6.32$. This becomes evident at $\mathrm{pH}>8$ when $\mathrm{Fe}$ and $\mathrm{Al}$ are out of solution for both ratios. Mo concentration thereafter increases to 0.08 $\mathrm{mg} / \mathrm{L}$ or greater. Se is observed to follow the same trend as Mo remaining at lower concentration at $\mathrm{pH}<$ 6.32 increasing as the $\mathrm{pH}$ approaches 8 (Table 3 ). This is more evident for the 1:3 FA: AMD ratio. Se also exists as oxyanion at neutral to alkaline $\mathrm{pH}$ and its removal could be through formation of metal selenites and selenates or adsorption on Fe, Al-oxides, oxyhydroxides.

\section{Selective sequential extractions (SSE)}

The hypothesis that major and trace elements from both fly ash and AMD are transformed into non-labile mineral phases was tested. 

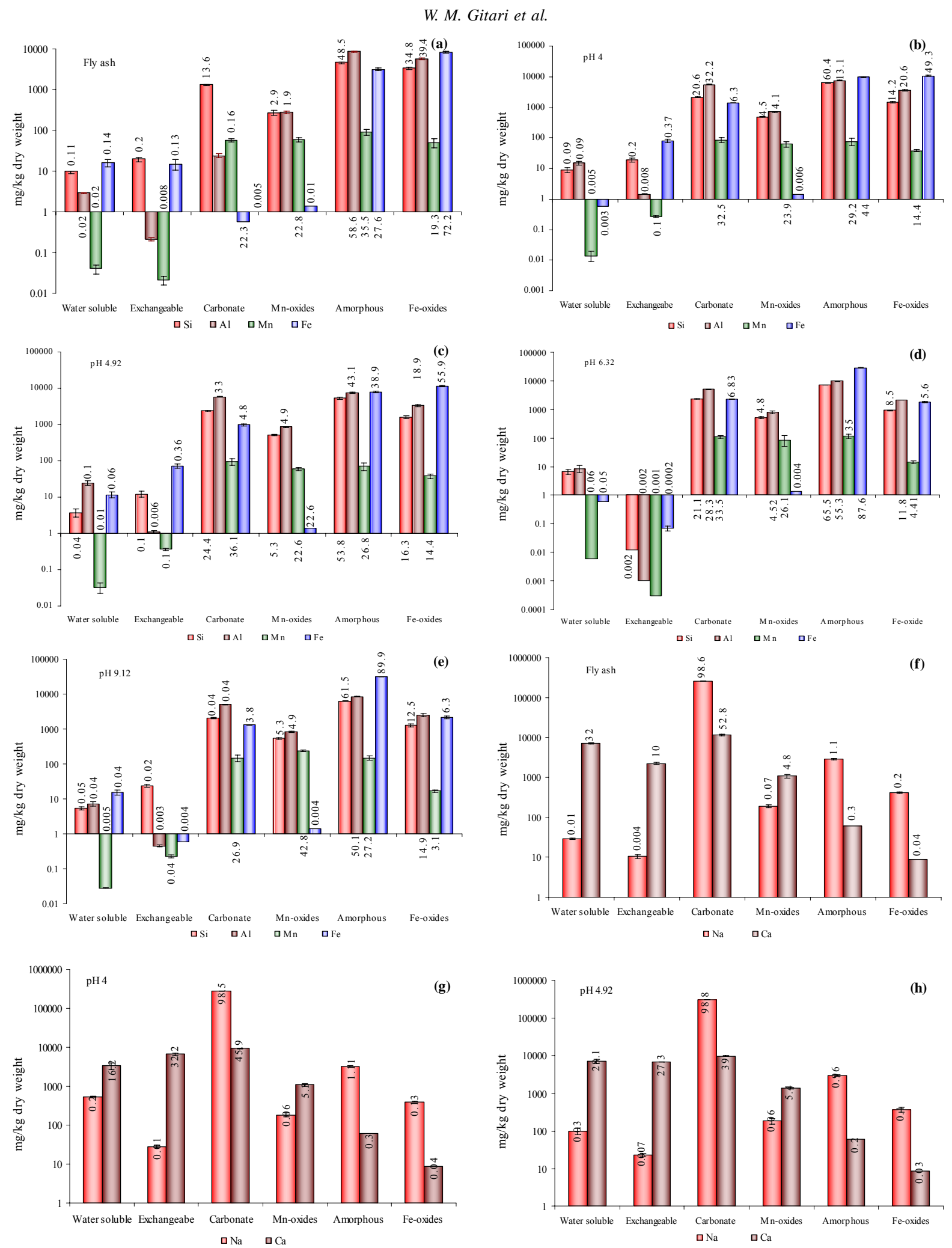

Fig. 3: Extractable concentrations ( $\mathrm{mg} / \mathrm{kg}$ dry weight) for various fractions as a function of $\mathrm{pH}$ (numbers on the bars represent $\%$ contribution of each element for each extracted fraction for fly ash and solid residues) 
Int. J. Environ. Sci. Tech., 7 (3), 519-534, Summer 2010
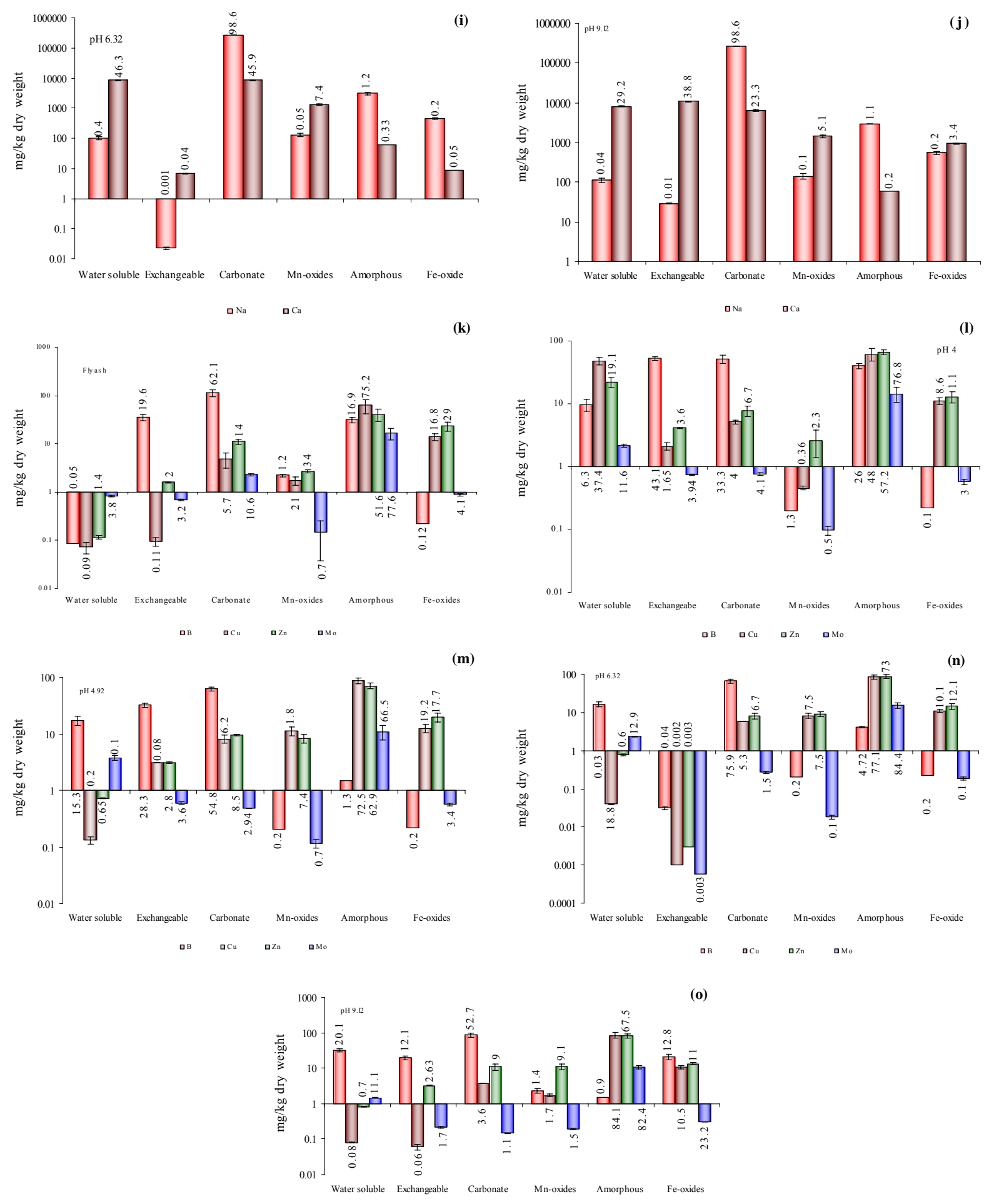

Fig. 3 (Continued): Extractable concentrations $(\mathrm{mg} / \mathrm{kg}$ dry weight) for various fractions as a function of $\mathrm{pH}$ (numbers on the bars represent \% contribution of each element for each extracted fraction for fly ash and solid residues) 
The residue fraction after sequential extraction was ignored since it contains non-labile elements locked up in the residue aluminosilicate matrix of the fly ash and was assumed to be of less significance in dictating the redistribution of the elements in the resulting mineral phases. The results are discussed with respect to the increase in $\mathrm{pH}$ and precipitation of $\mathrm{Fe}, \mathrm{Mn}$ and $\mathrm{Al}$, the major species in AMD. The total extracted amounts in $\mathrm{mg} / \mathrm{kg}$ dry weight for the six fractions is used to derive the $\%$ contribution of each element for each extracted fraction for fly ash and solid residues collected at $\mathrm{pH} 4,4.92,6.32$ and 9.12. The results of the sequential extraction are presented in Fig. 3.

\section{Al, Fe, Mn and Si concentration profiles}

The distribution of $\mathrm{Al}, \mathrm{Fe}$ and $\mathrm{Mn}$ in the fly ash indicates their occurrence in the amorphous and in crystalline Fe and Mn-bearing phases (Fig. 3 a). On contact with AMD these solid phases release Fe, Mn and $\mathrm{Al}$ into solution which on elevation of $\mathrm{pH}$ reprecipitates to form amorphous (oxy) hydroxides. The trends for the three elements represents a relocation to the amorphous fraction as the $\mathrm{pH}$ of the reaction mixture increases (Figs. $3 \mathrm{~b}-\mathrm{e}$ ). The high proportion of $\mathrm{Al}(39.4 \%)$ in $\mathrm{Fe}$-oxide fraction in fly ash represents its occurrence as $\mathrm{Ca}_{6} \mathrm{Al}_{4} \mathrm{Fe}_{2} \mathrm{O}_{15}$ crystalline phases (Mattigod et al., 1990) and the decrease in content in this fraction as the $\mathrm{pH}$ increases probably represents its dissolution and relocation to the carbonate and amorphous phases (Figs. $3 \mathrm{~b}-\mathrm{e}$ ). At $\mathrm{pH} 4$ a significant portion $(32.2 \%)$ is retained in the carbonate fraction. The solid residues at $\mathrm{pH} 4$ were collected after only 3 min of reaction time which means pockets of high alkalinity accompanied by ingress of $\mathrm{CO}_{2}$ existed especially at the surface of fly ash particles that could have led to local precipitation of metal carbonates (Fig. $3 \mathrm{~b}$ ). At $\mathrm{pH}>6.32$ the amorphous fraction became the dominant phase retaining Al, indicating a significant proportion of $\mathrm{Al}$ from $\mathrm{AMD}$ was hydrolyzing to form amorphous (oxy) hydroxides. However the carbonate fraction still retains a significant proportion at this $\mathrm{pH}$ range (28.3-30 \%) (Figs. $3 \mathrm{~d}$ and e).

The high \% (22.3) of Mn in the carbonate and Mnoxide fraction (22.8\%) (Fig. 3 a) indicates the presence of $\mathrm{Mn}$ in the fly ash as $\mathrm{MnCO}_{3}, \mathrm{MnO}$ or $\mathrm{Mn}_{3} \mathrm{O}_{4}$ respectively (Eary et al., 1990). The $19.3 \%$ present in Fe-oxide fraction represents Mn present in the spinel type solids which include magnetite, ferrite and hematite (Eary et al., 1990). A significant portion
(35.5\%) is locked up in the amorphous phase (Fig. 3a). At $\mathrm{pH} 4-5$ there is increased content in the carbonate fraction due to local pockets of high alkalinity and ingress of $\mathrm{CO}_{2}$ leading to formation of carbonates. At $\mathrm{pH} 6.32$ the amorphous and carbonate fractions (Fig. 3d) become significant in the retention of Mn. However as the solution attains $\mathrm{pH} 9.12$ the Mn-oxide and amorphous fractions become important (Fig. 3 e). At $\mathrm{pH}>7 \mathrm{Mn}^{2+}$ oxidation is fast (Eary et al., 1990) and PHREEQC modeling predicted precipitation of manganite.

$\mathrm{Fe}$ is present in fly ash mainly as crystalline Feoxides $(72.2 \%)$ and in amorphous form probably as $\mathrm{Ca}$, $\mathrm{Al}$ ferric phases (Mattigod et al., 1990). These phases on contact with highly acidic AMD undergo dissolution releasing $\mathrm{Fe}^{3+}$ into the reaction mixture. This is observed in the decreased content in the Fe-oxide and amorphous fraction at $\mathrm{pH} 4$ (Fig. 3 b). However a significant proportion is relocated to the carbonate fraction at this $\mathrm{pH}$ re-affirming the existence of local pockets of high alkalinity and ingress of $\mathrm{CO}_{2}$ leading to the precipitation of metal carbonates. As the solution attains $\mathrm{pH} 6.32$ the amorphous fraction becomes significant in retention of Fe (87.6-89.9\%) (Figs. $3 \mathrm{~d}$ and e). This coincides with the $\mathrm{pH}$ of optimum oxidation $\mathrm{Fe}^{2+}$ and hydrolysis of $\mathrm{Fe}^{3+}$ which indicates that it is hydrolyzing mainly to amorphous $\mathrm{Fe}$ (oxy) hydroxides.

The Si trend shows a redistribution amongst three fractions as the fly ash interacts with AMD: amorphous, Fe-oxide and carbonate fractions. At $\mathrm{pH}>4$ the amorphous fraction becomes most important in retention of $\mathrm{Si}$ (Figs $3 \mathrm{c}-\mathrm{e}$ ).

\section{Ca and Na concentration profile}

$\mathrm{Ca}$ trends in the extracted fractions represent a redistribution between three phases: water soluble, exchangeable and carbonate (Figs. $3 \mathrm{f}-\mathrm{j}$ ). In the fly ash $\mathrm{Ca}$ is highest in carbonate fraction $(52.8 \%)$ indicating its presence as a carbonate phase and water soluble fraction $(32 \%)$. As dissolution occurs on contact with AMD redistribution occurs in the three fractions, however water soluble and the carbonate fractions still retain a significant proportion of the total $\mathrm{Ca}$. Retention of $\mathrm{Ca}$ in the carbonate fraction despite dissolution at acidic $\mathrm{pH}$ indicates that formation of calcite due to ingress of $\mathrm{CO}_{2}$ was taking place. Formation of soluble anhydrite or gypsum at acidic $\mathrm{pH}$ and high $\mathrm{SO}_{4}^{2-}$ content could also account for the increased retention in the water soluble fraction (Fig. $3 \mathrm{~g}$ ). At pH 9.12 the 
exchangeable fraction becomes significant in retention of $\mathrm{Ca}$ as water soluble and carbonate fractions (Fig. $3 \mathrm{j}$ ).

Na shows redistribution amongst three fractions: water soluble, amorphous oxides and crystalline Feoxide. In the fly ash $\mathrm{Na}$ is mainly present in the carbonate fraction (98.6\%) which suggests its occurrence as a carbonate. Na remains retained in the carbonate fraction as the $\mathrm{pH}$ increases to 9.12, and remains at $\mathrm{H}^{\prime \prime} 1.0 \%$ in the amorphous fraction for the entire experiment (Fig. 3 i). However it should be noted that there is release of Na into the reaction mixture judging by the total of the six fractions as the $\mathrm{pH}$ increases (Figs. $3 \mathrm{f}-\mathrm{j}$ ). The high retention of both elements in the carbonate fraction at $\mathrm{pH} 4$ (Fig. $3 \mathrm{f}$ ) suggests that at $3 \mathrm{~min}$ of reaction time due to inadequate mixing local pockets of high alkalinity existed especially at the particle surfaces and ingress of $\mathrm{CO}_{2}$ accompanied by the formation of $\mathrm{CO}_{3}{ }^{2-}$ could have led to the precipitation of $\mathrm{CaCO}_{3}$ and $\mathrm{Na}_{2} \mathrm{CO}_{3}$.

\section{$\mathrm{Cu}$ and $\mathrm{Zn}$ concentration profile}

The $\mathrm{Cu}$ profile shows redistribution within three fractions: amorphous, water soluble and Mn-Fe-oxide fractions as the $\mathrm{pH}$ increases (Figs. $3 \mathrm{k}-\mathrm{o}$ ). The high $\mathrm{Cu}$ percentage (75.2\%) in the amorphous fraction in fly ash indicates it's presence in the amorphous aluminosilicate glass matrix (Hullet et al., 1980). The $16.8 \%$ (Fig. 3k) in Fe-oxide fraction shows incorporation in the magnetic fraction consisting of spinel type solids such as magnetite, ferrite and hematite (Hullet et al., 1980). At pH 4 dissolution of the $\mathrm{Cu}$ bearing mineral phases is observed to occur with relocation to the carbonate fraction due to the local development of high concentrations of $\mathrm{CO}_{3}{ }^{2-}$ as result of ingress of $\mathrm{CO}_{2}$ (Fig. $3 \mathrm{l})$. At $\mathrm{pH}>5$ the amorphous and Fe-Mn-oxide fraction become significant in retention of $\mathrm{Cu}$ indicating the importance of adsorption processes in controlling the attenuation of $\mathrm{Cu}$ (Figs. $3 \mathrm{~m} \mathrm{-} \mathrm{o).} \mathrm{Zn}$ is observed to be undergoing redistribution in amorphous, Fe, Mn-oxides fractions. The carbonate fraction seems to be important at $\mathrm{pH} 4$ (Fig. $3 \mathrm{f}$ ) and as the solution attains $\mathrm{pH}>5$ (Figs. $3 \mathrm{~m}-\mathrm{o}$ ). The significance of the two fractions: amorphous, Mn Fe-oxide, indicates the importance of the adsorption processes in controlling the attenuation of $\mathrm{Zn}$ as the $\mathrm{pH}$ increases.

\section{$B$ and Mo concentration profiles}

In the fly ash $62.1 \%$ of the B is present in the carbonate fraction and a significant fraction is present in the exchangeable (19.6\%) and amorphous fractions (16.9\%) (Fig. 3k). Several authors have observed association of borate-boron with calcite (Kitano et al., 1978; Akira et al., 2005) and this probably explains the high concentration observed in the carbonate fraction. An observation of $\mathrm{Ca}$ trends indicate occurrence of $52.8 \%$ in the carbonate fraction which reinforces the borate-boron-calcite association at alkaline $\mathrm{pH}$. A significant percentage (77.6\%) of Mo is present in the amorphous fraction in the fly ash and also in the carbonate fraction (10.6\%) (Fig. $3 \mathrm{k}$ ).

An observation of the sequential extraction results (Figs. $3 \mathrm{k}-\mathrm{o}$ ) indicates that $\mathrm{B}$ is being re-distributed among three fractions: exchangeable, carbonate and amorphous oxides as the $\mathrm{pH}$ increases. The increase in $\mathrm{B}$ concentration in the exchangeable fraction at $\mathrm{pH} 4.92$ probably reflects the adsorption of released $\mathrm{B}(\mathrm{OH})_{3}$. As the $\mathrm{pH}$ increases to $>5$ most of the $\mathrm{B}$ gets partitioned to the carbonate and water soluble fraction with a substantial portion being retained by the crystalline Fe-oxide fraction. An important feature to note is that amorphous fraction is important in retention of $\mathrm{B}$ at $\mathrm{pH}$ 4 and 6.32. This corresponds to the $\mathrm{pH}$ at which $\mathrm{Fe}^{3+}$ and $\mathrm{Al}$ are precipitated and $\mathrm{pH} 6.32$ at which hydrolysis and precipitation of $\mathrm{Fe}^{2+}$ to amorphous $\mathrm{Al}$ and ferric (oxy) hydroxides occur.

Mo seem to be redistributed within two main fractions: water soluble and the amorphous oxide (Figs. $3 \mathrm{k}-\mathrm{o}$ ). As the $\mathrm{pH}$ increases and dissolution of the amorphous glass phase in the fly ash occurs, Mo is translocated to the water soluble fraction. This could be a limitation in the application of the fly ash in this process. However at $\mathrm{pH} 6.32$ a significant portion (84.4\%) of the total Mo is retained in the amorphous precipitates (Fig. 3 l). This indicates that hydrolysis and precipitation of $\mathrm{Fe}^{2+}$ has an impact in the removal of Mo.

\section{CONCLUSION}

The major inorganic species $\mathrm{Fe}, \mathrm{Mn}, \mathrm{Al}$ and $\mathrm{SO}_{4}^{2-}$ seem to be mainly removed through precipitation of amorphous oxides, (oxy) hydroxides and basic hydroxyl sulphates. Precipitation and adsorption on the precipitated amorphous oxides seems to be the main mechanisms of removal of the minor species such as $\mathrm{Cu}, \mathrm{Zn}, \mathrm{Mo}$ and $\mathrm{B}$.

The sequential extraction results reveals that the carbonate fraction is important in retaining all the contaminants at $\mathrm{pH} 4$. This is postulated to be mainly 
due to local pockets of high alkalinity that existed on initial contact of fly ash particles with AMD. Dissolution of fly ash components is confirmed through the decrease of $\mathrm{Fe}$ in the Fe-oxide fraction at $\mathrm{pH}$ 4. The importance of the amorphous fraction is confirmed as an important fraction in the retention of the major species $\mathrm{Mn}, \mathrm{Fe}$ and $\mathrm{Al}$ at $\mathrm{pH}>6.32$. A substantial proportion of $\mathrm{Fe}$ is translocated to the amorphous fraction at $\mathrm{pH} 6.32$ confirming that precipitation of $\mathrm{Fe}$ as amorphous oxides is a significant clean-up mechanism in this process. $\mathrm{Cu}$ and $\mathrm{Zn}$ are also observed to increase in the amorphous fraction at $\mathrm{pH}>6.32$ emphasizing the importance of adsorption processes in the removal of the minor species. Hydrolysis and precipitation of $\mathrm{Fe}^{3+}$ was observed to have an impact in the attenuation of Mo. That B has a strong association with calcite formation is evidenced by the increased content in the carbonate fraction at $\mathrm{pH}>5$ and that the amorphous fraction also plays an important role at $\mathrm{pH} 4-6.32$.

The alkali metals $\mathrm{Na}$, and $\mathrm{Ca}$ after the initial dissolution are mainly retained in the carbonate and amorphous fractions with a substantial fraction also retained in water soluble fraction. Mo was retained in the water soluble fraction at $\mathrm{pH}>4$. The retention in the water soluble fraction presents a risk in the disposal of these solid residues due to possible re-solubilization on contact with water or acidic leachates.

That the amorphous fraction was observed to be the most important in retention of the major and minor species at $\mathrm{pH}>6.32$ implies that the concentration of total $\mathrm{Fe}$ and $\mathrm{Al}$ in the AMD being treated will have a direct effect on the efficiency of the treatment process.

\section{ACKNOWLEDGEMENTS}

The authors wish to express their gratitude to the Water Research Commission (WRC), Coaltech 2020 Consortium, and the National Research Foundation (NRF) for financial support to perform this study. The authors would also like to express their gratitude to ESKOM and Anglocoal for their assistance in the collection of samples. Special thanks to the Chemistry Department of the University of the Western Cape for the assistance provided during this study.

\section{REFERENCES}

Abbott, D. E.; Essington, M. E.; Mullen, M. D.; Ammons, J. T., (2001). Fly ash and lime-stabilized biosolid mixtures in mine spoil reclamation: Simulated weathering. J. Environ. Qual., 30 (2), 608-616 (9 pages).
Abdel-Ghani, N. T.; Hegazy, A. K.; El-Chaghaby, G. A., (2009). Typha domingensis leaf powder for decontamination of aluminium, iron, zinc and lead: Biosorption kinetics and equilibrium modeling. Int. J. Environ. Sci. Tech., 6 (2), 243248 (6 pages).

Adamo, P.; Dudka, S.; Wilson, M. J.; McHardy, W. J., (1996). Chemical and mineralogical forms of $\mathrm{Cu}$ and $\mathrm{Ni}$ in contaminated soils from the Sudbury mining and smelting region, Canada. Environ. Pollut., 91 (1), 11-19 (9 pages).

Adriano, D. C.; Page, A. L.; Elseewi, A. A.; Chang, A. C.; Straughan, I., (1980). Utilization and disposal of fly ash and other coal residues in terrestrial ecosystems: A review. J. Environ. Qual., 9 (3), 333-344 (12 pages).

Agyei, N. M.; Strydom, C. A.; Potgieter, J. H., (2002). The removal of phosphate ions from aqueous solution by fly ash, slag, ordinary Portland cement and related blends. Cement Concret. Res., 32 (12), 1889-1897 (9 pages).

Akira, I.; Yuka, S.; Tsunenoni, N.; Hirokazu, T.; Akira, O.; Shinji, K., (2005). Leaching characteristics of boron and selenium for various coal fly ashes. Fuel., 84 (5), 479-485 (7 pages)

Ball, J. W.; Nordstrom, D. K., (1991). WATEQ4F-user's manual with revised thermodynamic data base and test cases for calculating speciation of major, trace and redox elements in natural waters. U.S. Geological Survey Open-File., Report 90-129 (40 pages)

Beckett, P. H. T., (1988). The use of extractants in studies on the trace metals in soils, sewage sludges and sludge-treated soils. Adv. Soil Sci., 9 (5), 144-175 (32 pages).

Brittons, H. T. S., (1956). Hydrogen ions, $4^{\text {th. }}$ Ed. Chapman and Hall, London.

Campbell, A., (1999). Chemical, physical and mineralogical properties associated with the hardening of some South African fly ashes. M.Sc. Thesis University of CapeTown, South Africa.

Carlson, C. L.; Adriano, D. C., (1993). Environmental impacts of coal combustion residues. J. Environ. Qual., 22 (2), $227-$ 247 (21 pages).

Chao, T. T., (1972). Selective dissolution of manganese oxides from soils and sediments with acidified hydroxylamine hydrochloride. Soil Sci. Soc. Am. J., 36 (5), 764-768 (5 pages).

Cornell, R. M.; Schwertmann U., (1996). The iron oxides. $\mathrm{VCH}$ Verlagsgesellchaft, $\mathrm{MBH}$.

Cravotta, C. A. I.; Mary, K. T., (1999). Limestone drains to increase $\mathrm{pH}$ and remove dissolved metals from acidic mine drainage. Appl. Geochem., 14 (5), 581-606 (26 pages).

Eary, L. E.; Rai, D.; Mattigod, S. V.; Ainsworth, C. C., (1990). Geochemical factors controlling the mobilization of inorganic constituents from fossil fuel combustion residues: II, Review of the Minor Elements. J. Environ. Qual., 19 (2), 202-214 (13 pages).

Erol, M., KüÇükbayrak, S.; Ersoy-MeriÇboyu, A.; Uluba, T., (2005). Removal of $\mathrm{Cu}^{2+}$ and $\mathrm{Pb}^{2+}$ in aqueous solutions by fly ash. Energy Conver. Manage., 46 (7-8), 1319-1331 (13 pages).

Feng, X. D.; Dang, Z.; Huang, W. L.; Yang, C., (2009). Chemical speciation of fine particle bound trace metals. Int. J. Environ. Sci. Tech., 6 (3), 337-346 (10 pages).

Foner, H. A.; Thomas, L. R.; Hower, C. J.; Uschi, M. G., (1999). Characterization of fly ash from Israel with 
reference to its possible utilization. Fuel., 78 (2), 215 223 (9 pages).

Furr, A. K.; Parkinson, T. F.; Hinrichs, R. A.; Van Campen, D. R.; Bache, C. A.; Gutenmann, W. H.; John J. L. E. S.; Pakkala, I. S.; Lisk, D. J., (1977). National survey of elements and radioactivity in fly ashes: Absorption of elements by cabbage grown in fly ash soil mixtures. Environ. Sci. Tech., 11 (13), 1194-1201 (8 pages).

Gitari, M. W.; Petrik, L. F.; Etchebers, O.; Key, D. L.; Iwuoha, E.; Okujeni, C., (2006). Treatment of acid mine drainage with fly ash: Removal of major contaminants and trace elements. J. Environ. Sci. Health-Part A., A 41, (8), 1729-1747 (19 pages).

Gitari, M. W.; Petrik, L. F.; Etchebers, O.; Key, D. L.; Okujeni, C., (2008). Utilization of fly ash for treatment of coal mines wastewater: Solubility controls on major inorganic contaminants. Fuel., 87 (12), 2450-2462 (13 pages).

Hullet, L. D.; Weinbeger, A. J., (1980). Some etching studies of the microstructure and composition of large aluminosilicate particles in fly ash from coal-burning power plants. Environ. Sci. Tech., 14 (8), 965-970 (6 pages).

Jenke, R. D.; Gordon, K. P., (1983). Chemical changes in concentrated, acidic, metal-bearing waste waters when treated with lime. Environ. Sci. Tech., 17 (4), 217-223 (7 pages).

Jenne, E. A., (1977). Trace element sorption by sediments and soils- site and processes. in: Chappell, W.; Peterson, S. K. (Eds.), Proc. Symp. Molybdenum in the Environment. MarcelDekker, New York, 425-552 (28 pages).

Karbassi, A. R.; Monavari, S. M.; Bidhendi, G. R. N.; Nouri, J., Nematpour, K., (2008). Metal pollution assessment of sediment and water in the Shur River. Environ. Monitor. Assess., 147 (1-3), 107-116 (10 pages).

Kitano, Y.; Minoru, O.; Masatoshi, I., (1978). Co-precipitation of borate-boron with calcium carbonate. Geochem. J., 12 (3), 183-189 (7 pages).

Krüger, J. E., (2003). South African fly ash: A cement extender. A South Coal Fly Ash Association publication.

Ma, L. Q.; Rao, G. N., (1997). Chemical fractionation of cadmium, copper, nickel and zinc contaminated soils. J. Environ. Qual., 26 (1), 259-264 (6 pages).

Mahvi, A. H., (2008). Application of agricultural fibers in pollution removal from aqueous solution. Int. J. Environ. Sci. Tech., 5 (2), 275-285 (11 pages).

Maree, J. P.; Du Plessis, P.; Van der Walt, C. J., (1992). Treatment of acidic effluents with limestone instead of lime. Water Sci. Tech., 26 (1-2) 345-355 (11 pages).

Maree, J. P.; Van Tonder, G. J.; Millard, P., (1996). Underground neutralization of mine water with limestone. Water Research Commission. Report No. 609/1/96.

Mattigod, S. V.; Dhanpat, R.; Eary, L. E.; Ainsworth, C. C., (1990). Geochemical factors controlling the mobilisation of inorganic constituents from fossil fuel combustion residues: 1. Review of the major elements. J. Environ. Qual., 19 (2), 188-201 (14 pages).

Mohsenzadeh, F.; Nouri, J.; Ranjbar, A.; Mohammadian Fazli, M.; Babaie, A. A., (2006). Air pollution control through kiln recycling by-pass dust in a cement factory: Iran. J. Environ. Health Sci. Eng., 3 (1), 5-8 (4 pages).

Muller, J.; Seiler, K. P., (1999). Relevance of self-sealing processes in pyrite sinters for heavy metal mobility.
Armanson, A. H. (Ed.), $5^{\text {th. }}$ Symposium in Geochemistry of the Earth's Surface. Balkema, Rotterdam, 211-214 (4 pages).

Nameni, M.; Alavi Moghadam, M. R.; Arami, M., (2008). Adsorption of hexavalent chromium from aqueous solutions by wheat bran. Int. J. Environ. Sci. Tech., 5 (2), 161-168 (8 pages).

Nordstrom, D. K.; Alpers, C. N., (1999). Geochemistry of acid mine waters. in: Plumlee, G. S.; Logsdon, M .J. (Eds.), The environmental geochemistry of mineral deposits part A. processes, techniques and health issues, Reviews in Economic Geology., 6A, 133-160, SEG Inc, Michigan.

Okafor, E. Ch.; Opuene, K., (2007). Preliminary assessment of trace metals and polycyclic aromatic hydrocarbons in the sediments. Int. J. Environ. Sci. Tech., 4 (2), 233-240 (8 pages).

Page, A. L.; Elseewi, A. A.; Straughan, I., (1979). Physical and chemical properties of fly ash from coal-fired power plants with reference to environmental impacts. Resid. Rev., 71, 83-120 (38 pages).

Parkhurst, D. L., (1995). User's guide to PHREEQC-A computer program for speciation, reaction-path, advective-transport, and inverse geochemical calculations: U.S. Geological Survey Water-Resources Investigations Report No 95-4227.

Pérez-López, R.; Nieto, J. M.; Almodóvar, G. R., (2007a). Utilization of fly ash to improve the quality of the acid mine drainage generated by oxidation of a sulphide-rich mining waste: Column experiements. Chemosphere, 67 (8), 1637-1646 (28 pages).

Pérez-López, R.; Cama, J.; Nieto, J. M.; Ayora, C., (2007b). The iron-coating role on the oxidation kinetics of a pyritic sludge doped with fly ash. Geochim. Cosmochim. Acta., 71 (7), 1921-1934 (14 pages).

Pérez-López, R.; Álvarez-Valero, A. M.; Nieto, J. M.; Almodóvar, G. R., $(2007 \mathrm{c})$. Mineralogy of the hardpan formation processes in the interface between sulphiderich sludge and fly ash: Applications for acid mine drainage mitigation. Am. Mineralog., 92 (11-12), 1966-1977 (12 pages).

Plank, C. O.; Martens, D. C., (1974). Boron availability as influenced by application of fly ash to soil. Soil Sci. Soc. Am. Proc., 38 (6), 974-977 (4 pages).

Reardon, E. J.; Czank, C. A.; Warren, C. J.; Dayal, R., Johnson, H. M., (1995). Determining controls on element concentrations in fly ash leachate. Waste Manage. Res., 13 (5), 435-450 (16 pages).

Seth, R.; Elliot, W. C., (2000). The effects of $\mathrm{pH}$ regulation upon the release of sulfate from ferric precipitates formed in acid mine drainage. Appl. Geochem., 15 (1), 27-34 (8 pages).

Shuman, L. M., (1985). Fractionation method for soil micronutrients. Soil Sci., 140 (1), 11-22 (12 pages).

Spears, D. A.; Lee, S., (2004). Geochemistry of leachates from coal ash, Geological Society, London. Special publications. 236, 619-639 (21 pages).

Sposito, G., (1983). The chemical forms of trace metals in soils. Thornton, I. (Ed.). Applied Environmental Geochemistry. Academic press, London, 123-170 (49 pages).

Stumm, W.; Lee, G. F., (1961). Oxygenation of Ferrous iron. Ind. Eng. Chem., 53 (2), 143-146 (4 pages). 
Tessier, A.; Campell, P. G. C.; Bison, M., (1979). Sequential extraction procedure for the speciation of particulate trace metals. Anal. Chem., 51 (7), 844-850 (7 pages).

Uhlmann, W. H.; Buttcher, O. T.; Steinberg, C. E. W., (2004). Buffering of acidic mine lakes: The relevance of surface exchange and solid bound sulphate. Mine. Water Environ., 23 (1), 20-27 (8 pages).

Ure, A.; Quevaullier, P. H.; Muntau, H.; Griepink, B., (1993). Speciation of heavy metals in soils and sediments. An account of the improvement and harmonization of extraction techniques undertaken under the auspices of the BCR of the CEC. Int. J. Environ. Analyt. Chem., 51 (1-4), 135-151 (17 pages).

Xenidis, A.; Evangelia, M.; Ioannis P., (2002). Potential use of lignite fly ash for the control of acid generation from sulphidic wastes. Waste Manage., 22 (6), 631-641 (11 pages).

Younger, P. L.; Banwart, S. A.; Hedin, R. S., (2002). Mine water, hydrology, pollution, remediation. Kluwer academic Publishers Dordrecht. Chapter Two: Mine water chemistry.

\section{AUTHOR (S) BIOSKETCHES}

Gitari, W. M., Senior Lecturer, Department of Ecology and Resource Management, School of Environmental Sciences, University of Venda, South Africa. Email: mugera.gitari@univen.ac.za

Leslie, F. P., Senior Lecturer, Department of Chemistry, University of the Western Cape and Research Leader of Environmental and Nano Sciences Group, South Africa. Email: lpetrik@uwc.ac.za

Key, D. L., Full Professor, Department of Chemistry, University of the Western Cape, South Africa. Email: dkey@uwc.ac.za

Okujeni, C., Full Professor, Department of Earth Sciences, University of the Western Cape, South Africa. Email: cokujeni@uwc.ac.za

How to cite this article: (Harvard style)

Gitari, W. M.; Leslie, F. P.; Key, D. L.; Okujeni, C., (2010). Partitioning of major and trace inorganic contaminants in fly ash acid mine drainage derived solid residues. Int. J. Environ. Sci. Tech., 7 (3), 519-534. 